
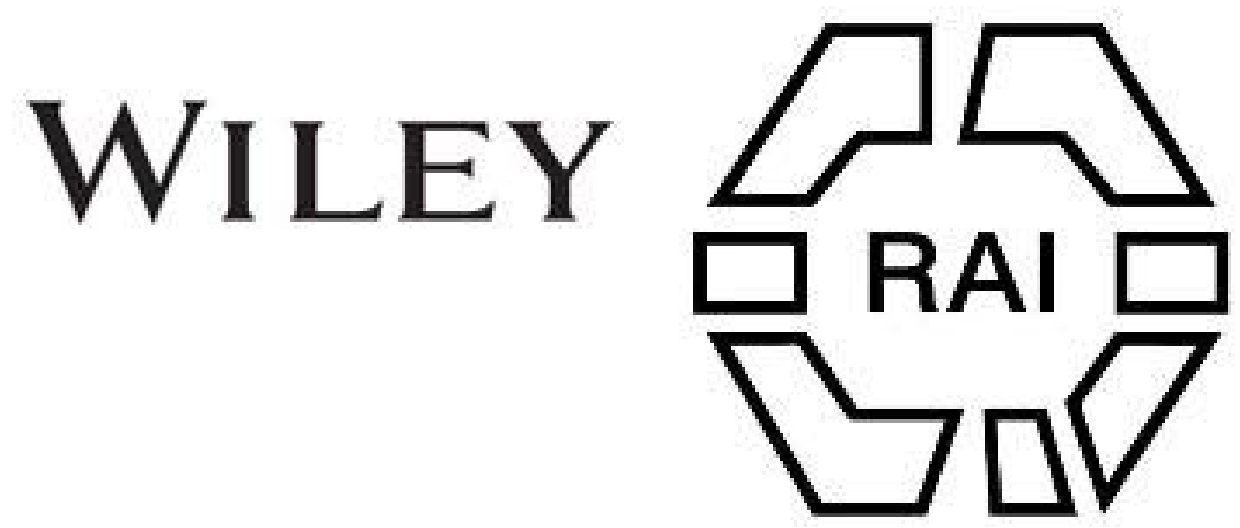

4. External Evidences Affecting the Problem of the Age of Ogham Writing in Ireland. Author(s): R. A. Stewart Macalister

Source: Man, Vol. 2 (1902), pp. 6-7

Published by: Royal Anthropological Institute of Great Britain and Ireland

Stable URL: http://www.jstor.org/stable/2840556

Accessed: 26-06-2016 09:55 UTC

Your use of the JSTOR archive indicates your acceptance of the Terms \& Conditions of Use, available at

http://about.jstor.org/terms

JSTOR is a not-for-profit service that helps scholars, researchers, and students discover, use, and build upon a wide range of content in a trusted digital archive. We use information technology and tools to increase productivity and facilitate new forms of scholarship. For more information about JSTOR, please contact support@jstor.org.

Wiley, Royal Anthropological Institute of Great Britain and Ireland are collaborating with JSTOR to digitize, preserve and extend access to Man 
Ireland : Ogham.

Two views of the age of Ogham writing in Ireland have been held and strenuously supported. The first regards all existing monuments as pre-Christian, and considers all crosses or other Christian symbols upon them as subsequent additions. The second considers the script itself (and consequently all examples of the use of the script) as entirely post-Christian in origin. No one seems willing to accept a compromise, whereby the script might be considered of pre-Christian origin, but continued in use till many years after the establishment of Christianity. This, however, seems the view most consistent with existing evidence.

While it may be regarded as axiomatic that stones found on Christian sites, or bearing Christian symbols, are of Christian origin-the theory that crosses are all superadded is quite too far-fetched to be admissible-there are some which are evidently examples of the reappropriation of Ogham monuments for subsequent Christian use. Of such stones the best example is at Kilfountain, near Dingle ; this bears on one face a cross and inscription, Ginten, in Irish letters ; on the edge is an entirely independent and no doubt earlier Ogham, Inisi. The two have nothing to do with each other. The stone found at Glenfahan, also near Dingle, bears two crosses and an inscription which there seems every reason to regard as an occult or magical formula. Such a formula can scarcely be a Christian invention, and its inventors must have had some sort of script in which to write it down. (On this stone see Trans. R.I.A., Vol. XXXI., p. 317.)

Thus even among stones with crosses upon them, of some the crosses are not conclusive evidence of date, and in others there is definite indication that the stone belongs to the Pagan-Christian overlap.

If now we turn our attention to stones not marked with the cross we find certain monuments which it would be very difficult to persuade ourselves (if we be unbiassed) are Christian. The three examples of Ogham writing found associated with stone circles need not be called in evidence, as in that case the monument mast precede the Ogham ; anything we know of stone circles suggests that they must be put back to an age quite too remote for writing to be conteinporary with them. But we find Ogham writing in other connexions as well in which the disparity of date is by no means a probable hypothesis. Examples are (1) the very pagan looking tumulus at Lugnagappul, near Auniscaul, co. Kerry ; a low mound of stones and earth, overgrown with furze, with stones set round its circumference-two of them Ogham inscribed. This monument is locally connected by tradition with a great battle, and is known as Cnocán un fhola, "the little hill of blood." It bears every indication of enclosing very instructive secrets. (2.) The great rude pillar-stone at Crag, near 'Tralee, inscribed, "Of Luguttis the Poet," and interesting as being the oldest monument of a poet in the British Islands. It would be difficult to conceive a more pagan looking monument, unless it be (3) the imposing stone alignment on the top of a hill at Droumatouk, near Kenmare. This consists of a magnificent slab of stone, about $12 \mathrm{ft}$. in beight, flanked on each side with two smaller but conspicuous stones. Who Lugunis, the occupant of this sepulchre, was, we do not know ; but he certainly owns a royal monument: (4.) Lastly, a stone recently discovered at Dromlusk, in the same district, is in point. This consists of two stones in north and south alignment; on the eastern face of the stone bearing the Ogham is a circie engraved, in exactly the same technique as the scoring of the letters. Though solar symbolism and the like are generally discredited and ridiculed hypotheses in explaining monuments like this, it is impossible to free the mind from them in examining this stone. The meridian alignment and the east-pointing circle are very suggestive in this direction. 
These examples make it at least admissible to donbt that all Ogham monnments are of the Christian period ; and it follows that the suript may reasonably be regarded as a pagan invention carried into the Christian epoch, and widely used long after the establishment of Christianity in Ireland.

R. A. S. MACALISTER.

\section{Folklore : Ireland.}

Casement.

Supplementary Note on Certain Wells in Ireland. (Cf. MaN, 5
01. 11.) By Roger Casement, British Consulate, Boma, Congo Free State.

In the article, On Certain Wells in Ireland, by Professor Rhŷs (MAN, 1901. 11), which is of uncommon interest, I observe that Sir Henry Blake speaks of a book by the Rev. Cæsar Otway, which he styles "Erris and Trelawney." I read the book many years ago, and if my memory serves me right, and with all respect to so distinguished an Irishman as Sir Henry Blake, the title should be "Erris and Tyrawley." Trelawney would be, I think, a Cornish name; Tyrawley is the name of a district in North Mayo.

The prefix Tyr (or Ter, as Sir Henry Blake himself applies it in speaking of the island of Termoncara) was one common in Celtic Ireland in territorial designations of tribal divisions of the country. We find it to-day in Tyrone (formerly Tyr or Tir-Owen), i.e., "the land of Owen"; Tyr-connell or Eoghan (now Donegal), i.e., the land of Conail or Connell, whose descendauts, the O'Donnells, were chiefs of 'Tyr-connell.

Regarding strange Irish wells, I enclose an account of some remarkable wells in the county of Antrim in 1683, as recorded by Mr: Richard Dobbs, of Castle Dobbs, in that county.

ROGER CASEMENT.

** We hope to publish under a subsequent number some extracts from the MS. of Richard Dobbs. Otway's " Erris and Tyrawley" was published in 1843.-ED.

Stonehenge.

Gowland.

The Recent Excavations at Stonehenge, with inferences as to the Origin, Construction, and Purpose of that Monument. Abstract

of a Report presented by W. Gowland, F.S.A., to the Society of Antiquaries, December 19th, 1901.

The fall of one of the uprights of the outer circle of Stonehenge on the night of 31 st December 1900 ( $c f$. MaN, 1901. 18) led the owner, Sir E. Antrobus, Bart,, to permit a careful examination of the remainder by a committee appointed for this purpose, and to execute the works recommended by this committee for the protection of the stones from further damage. The engineering work was planned by Mr. Carruthers and superintended by Mr. Detmer Blow. The exploratory work was conducted by Mr. Gowland, and a most careful record was kept of every detail of the incidental finds.

The primary object, the replacement of the "leaning-stone" (see illustration on next page) in its original erect position, was effected by enclosing the stone-which had declined from 77 degrees in 1650 to the dangerous angle of 61 degrees in 1901, and which showed three serious fissures on its upper side-in a cradle of stout timbers, and raising it with ropes and winches, while supporting it also on the underside by struts of stout timber. To secure it for the future the whole of the underlying soil was removed in successive sections down to the rock level and replaced by concrete; and it was in the course of this excavation that the discoveries to be described were made.

As to foundations, the "leaning stone" was found to go down $8 \mathrm{ft}$. below the surface datum, to terminate obliquely, and to rest upon two "sarsen" supports. Its fellow, the "recumbent stone," had beeu supported on one face by a pile of "sarsen" blocks, and on the other by two large blocks, by which a row of stone mauls (see below) was found, which seem to have been used to wedge the "recumbent stone" tight. If set back in its place thus indicated the "recumbent stone" would be exactly in line with the "leaniug stone." 